\title{
Prevalence of Voluntary Counseling and Testing Utilization and Its Associated Factors Among Merawi Preparatory School Students in Merawi Town, West Gojjam, Ethiopia
}

This article was published in the following Dove Press journal:

HIVIAIDS - Research and Palliative Care

\author{
Daba Abdissa (iD) \\ Mulat Tazebew (iD ${ }^{2}$ \\ Asfaw Gerbi (iD) \\ 'Department of Biomedical Sciences, \\ College of Medical Sciences, Institute of \\ Health Sciences, Jimma University, Jimma, \\ Ethiopia; ${ }^{2}$ Obstetrics and gynaecology \\ section, Shahura Primary Hospital, \\ Alepha Woreda, Shahura, Amhara \\ Regional State, Ethiopia
}

\begin{abstract}
Purpose: HIV/AIDS is a major public health problem in many parts of the world. Voluntary counseling and testing (VCT) is one of the essential strategies for its prevention and an entry point to AIDS care. Nevertheless, utilization of VCT is low in Ethiopia. Hence, the aim of this study was to assess the prevalence of VCT utilization and associated factors among Merawi preparatory school students, West Gojjam, Ethiopia.
\end{abstract}

Methods: An institution-based cross-sectional study was conducted from December 2 to 20, 2019 using a stratified random sampling method to enroll 365 participants. Data were collected using pretested structured self-administered questionnaires, entered into EpiData version 3.1 and exported to SPSS version 20 for analysis. A logistic regression was used to determine an association between a number of independent variables and dependent variables. Adjusted odds ratios were calculated at $95 \% \mathrm{CI}$ and considered significant with a $\mathrm{p}$ value of $\leq 0.05$.

Results: The mean age of participants was $20.2 \pm 2.6$ years and more than half $(52.6 \%)$ of the respondents were male. From the study participants, $77.5 \%$ had good knowledge of VCT, $75 \%$ had a positive attitude towards VCT for HIV and $31.5 \%$ had undergone VCT for HIV. According to the multivariable logistic regression, having a boyfriend or girlfriend (AOR = 10.49; 95\% CI: 5.48, 20.09), discussing with parents about HIV (AOR = 3.63; 95\% CI: 1.97, 6.68), good knowledge (AOR: 3.9 ; 95\% CI: 1.80, 8.46) and positive attitude (AOR: 3.14; 95\% CI:1.45, 6.82) were significantly associated with VCT utilization.

Conclusion: The majority of the respondents had good knowledge and a positive attitude towards VCT; however, its utilization was low. Having a boyfriend or girlfriend, discussion with parents about HIV, good knowledge and positive attitude towards VCT were significantly associated with VCT utilization. Therefore, a health education program aimed at bringing behavioral change should be planned and implemented.

Keywords: prevalence, factors, voluntary counseling and testing, practice

\section{Introduction}

Voluntary counseling and testing (VCT) is the process by which a person undertakes confidential counseling, to empower the person to arrive at an informed choice with regard to learning his or her HIV status and receive advice on taking the appropriate activity. ${ }^{1}$ It is internationally recognized as an effective and important strategy for both prevention and care of HIV. ${ }^{2}$ It is instrumental in bringing about behavioral change, reducing unprotected sex and helping to reduce the incidence of HIV and other sexually transmitted infections. ${ }^{3}$ 
HIV/AIDS has spread rapidly through the world; according to UNAIDS at the end of 2016, 36.7 million people worldwide were living with HIV/AIDS. According to global data of 2016 UNAIDS and AIDS, about $66 \%$ of new HIV infections occurred in sub-Saharan Africa. ${ }^{4}$ SubSaharan Africa carries a disproportionate burden of HIV, accounting for more than $70 \%$ of the global burden of infection. ${ }^{5}$ Ethiopia is one of the Sub-Saharan African countries which face the high burden of HIV/AIDS. In 2018 the prevalence of HIV/AIDS in Ethiopia was 0.9\%, ranging from $0.1 \%$ to $4.8 \%$ among people aged $15-49$ years. In 2017 an estimated 613,000 people were living with HIV and $30 \%$ of them were from the Amhara region. ${ }^{1}$

HIV/AIDS has caused enormous human suffering in the African continent. Its effects are not confined to the health sector, but families, schools, work places and businesses have also been badly affected. During 2010 alone, an estimated 1.2 million adults and children died due to AIDS-related illnesses in Sub-Saharan Africa. ${ }^{6}$

Teens and adults, especially adult and young women continue to be at the center of the epidemic. Almost a quarter of people living with HIV are below the age of 25. In sub-Saharan Africa, nearly 3.3 million youth are living with HIV. ${ }^{7}$ Young people aged 15-24 represent $45 \%$ of all new HIV infections. Lack of information, risky sexual behavior and limited access to services for youth are expected to fuel the epidemic. ${ }^{8}$ Besides, youths' vulnerability has been attributed to their high levels of sexual activity, increased incidence of risky sexual behaviors, and their inability to make accurate assessments of their own risk for HIV infection. ${ }^{1,9}$

Knowledge of one's HIV status is important for individuals to get HIV-related health care. ${ }^{10}$ Currently, many individuals with HIV do not know that they are infected and often start treatment when they are already significantly immunocompromised. This results in poor health outcomes and continuance of HIV transmission. ${ }^{11}$ The national demographic and health survey conducted in Ethiopia in 2011 showed that $36 \%$ of women and $38 \%$ of men have ever been tested for HIV. Over all, about six in every ten Ethiopians have never been tested for HIV. ${ }^{10}$ The proportion of VCT coverage among the adult population in Ethiopia was only $27 \% .^{12}$

Studies in several areas demonstrated that knowledge, attitude and practice (KAP) of preparatory school students towards VCT are low. The low uptake was found to be associated with ignorance, fear of being positive, lack of perception of being at risk, cost of VCT, inadequate number of VCT centers and stigmatization, with these constituting major hindrances to acceptance of VCT for $\mathrm{HIV}^{2,13-15}$ There is a scarcity of evidence in Ethiopia regarding KAP towards VCT among preparatory school students, especially in the study area. Moreover, youths constitute a significant proportion of people affected by HIV. Hence, this study was initiated to fill the gap among Merawi preparatory school students, West Gojjam, Northern Ethiopia.

\section{Materials and Methods Study Area, Study Design and Study Period}

An institutional-based cross-sectional study was conducted in Merawi preparatory school which is located in Merawi town, capital city of Mecha district in west Gojjam, Northern Ethiopia. Preparatory schools provide education for two years at the level of 11th and 12th grade. The data collection period was from December 2 to December 20, 2019.

\section{Population}

Source populations were all preparatory school students attending Merawi preparatory school, whereas the study subjects were preparatory students sampled from the source population who fulfilled the inclusion criteria.

\section{Eligibility Criteria}

Students who agreed to participate in the study were included, students who were sick or unable to speak and night-time students were excluded from the study.

\section{Sample Size Determination}

Since there is no similar study in the target group in our study area, the sample size was determined by single proportion formula: $n i \frac{=(z \alpha / 2) 2 p(1-p)}{d 2}$ using $\mathrm{Z}=1.96$, $\mathrm{P}=50 \%$ and $\mathrm{d}=0.05$, accordingly the sample size was 384. Since the total population were less than 10,000 adjustment was made by the following formula $n_{f}=\frac{n i}{1+\frac{n i}{N}}$ $\rightarrow \frac{384}{1+\frac{384}{3629}} \rightarrow \mathrm{n}_{\mathrm{f}}=347$

where $n_{f}$ is the sample size calculated by adjustment, ni was the initial sample size calculated by single proportion formula (384), $N$ was the total number of students (3629). By taking into consideration a $5 \%$ non-response rate, the final sample size was 365 . 


\section{Sampling Technique}

Stratified random sampling was used to enroll the study subjects. First the students were arranged based on their grade and then the sample population was proportionally assigned to each grade using the formula;

$$
\begin{aligned}
& n i=\frac{N i * n}{N} \\
& \text { Where } n i=\text { sample size for one stratum } \\
& N i=\text { Population size for one stratum } \\
& N=\text { total number of students } \\
& n=\text { total sample size }
\end{aligned}
$$

Accordingly, the result was figured as follow,

Grade $11=2272: n i=\frac{2272 * 365}{3629}=229$

Grade $12=1357: n i=\frac{1357 * 365}{3629}=136$

Then numbers of study participants for each stratum was allocated proportionally and samples were selected by simple random sampling technique using their number given to them in the school as a sampling frame. Based on these, 229 students from grade 11 and 136 students from grade 12 were enrolled.

\section{Data Collection Instrument}

Data were collected using a pretested self-administeredstructured questionnaire which was developed based on previous similar studies and was modified to the study setting. ${ }^{7,16,17}$ It was first prepared in English language and then translated to Amharic (local language) and again re-translated to English by language experts for consistency. It comprised three parts: part I related to students' socio-demographic background, part II students' knowledge regarding VCT, part III attitude towards VCT and students' practice of VCT (supplementary materials).

The data were collected by six diploma graduate nurses under the supervision of the principal investigator.

\section{Data Quality Assurance}

The data quality was assured by giving training to data collectors, pre-testing the questionnaires, and conducting daily supervision. Before actual data collection the questionnaire was pre-tested on $5 \%$ of the sample size at Damot preparatory school to check clarity of the instrument and the reliability of the questionnaire. Orientation was given to participants on how to fill the questionnaire and participants were allowed to ask when they had ambiguity for the questions. Collected data were checked for completeness and accuracy daily by the principal investigator. Two days of training was given for the data collectors by the principal investigator.

\section{Operational Definitions}

Knowledge: There were 5 questions which covered basic knowledge about VCT; each question assigned a score of 1 for each correct response and 0 for each incorrect answer.

Good knowledge: when the respondents answered more than $60 \%$ ( $\geq 3$ out of 5 ) of knowledge questions correctly.

Poor knowledge: when the respondents scored less than $60 \%$ on the knowledge questions.

Attitude: There were 6 questions regarding attitude towards VCT; it assigned score of 1 for each favorable response and 0 for each unfavorable response.

Positive attitude: when respondents gave a favorable response in more than or equal to half of the questions for attitude.

Negative attitude: when respondents unfavorably responded to more than half of the questions for attitude.

Practiced/utilized VCT: In this study context participants were considered to have practiced VCT if they reported to have experienced an HIV test at least once.

Having a boyfriend or girlfriend: Participants who were married or who are going to marry in the future.

\section{Data Entry, Processing and Analysis}

After coding and checking for completeness and consistency, data were entered into EpiData version 3.1 and then were exported to SPSS version 20 for analysis. Descriptive statistics were used to summarize and present the information in the form of mean, median, percentages, and tables with $95 \%$ confidence intervals for prevalence estimates. Variables having a $p$-value of $<0.25$ in the bivariable model were considered as candidates for multivariable regression. A backward stepwise multivariable logistic regression model was used to assess the associations between dependent and independent variables. From all the variables entered into the multivariable logistic regression model, those with p-value of $<0.05$ were considered to be statistically significant. Model fitness was also checked through the Hosmer-Lemeshow test and gave a $p$ value of 0.59 , indicating evidence of fitness of the model.

\section{Results}

\section{Socio-Demographic Characteristics of Participants}

A total of 365 students with a response rate of $96 \%$ participated in this study. The mean age of study subjects was $20.2 \pm 2.6$ years. More than half $(192 ; 52.6 \%)$ of the 
Table I Socio-Demographic Characteristics of Preparatory School Students in Merawi, West Gojjam, Ethiopia, 2019

\begin{tabular}{|c|c|c|c|c|c|}
\hline \multirow[t]{2}{*}{ Variables } & \multirow[t]{2}{*}{ Category } & \multirow[t]{2}{*}{ Number (\%) } & \multicolumn{2}{|l|}{ Sex } & \multirow{2}{*}{$\frac{X^{2}}{p \text { value }}$} \\
\hline & & & Male[N (\%)] & Female[N (\%)] & \\
\hline Age & $\begin{array}{l}15 \text { to } 19 \text { years } \\
\geq 20 \text { years }\end{array}$ & $\begin{array}{l}164(44.9) \\
201(55.1)\end{array}$ & $\begin{array}{l}89(52.3) \\
103(51.2)\end{array}$ & $\begin{array}{l}75(45.7) \\
98(48.8)\end{array}$ & 0.565 \\
\hline Marital status & $\begin{array}{l}\text { Married } \\
\text { Single }\end{array}$ & $\begin{array}{l}29(7.9) \\
336(92.1)\end{array}$ & $\begin{array}{l}12(41.4) \\
180(53.6)\end{array}$ & $\begin{array}{l}17(58.6) \\
156(46.4)\end{array}$ & 0.287 \\
\hline Religion & $\begin{array}{l}\text { Orthodox } \\
\text { Protestants } \\
\text { Others }^{\mathrm{a}}\end{array}$ & $\begin{array}{l}229(62.7) \\
72(19.7) \\
64(17.5)\end{array}$ & $\begin{array}{l}I I 7(5 I . I) \\
36(50) \\
39(60.9)\end{array}$ & $\begin{array}{l}112(48.9) \\
36(50) \\
25(39.1)\end{array}$ & 0.335 \\
\hline Ethnicity & $\begin{array}{l}\text { Amhara } \\
\text { Oromo } \\
\text { Others }^{b}\end{array}$ & $\begin{array}{l}314(86) \\
26(7.1) \\
25(6.8)\end{array}$ & $\begin{array}{l}162(51.6) \\
14(53.8) \\
16(64)\end{array}$ & $\begin{array}{l}152(48.4) \\
12(46.2) \\
9(36)\end{array}$ & 0.485 \\
\hline Residence & $\begin{array}{l}\text { Urban } \\
\text { Rural }\end{array}$ & $\begin{array}{l}157(43) \\
208(57)\end{array}$ & $\begin{array}{l}67(42.7) \\
125(60.1)\end{array}$ & $\begin{array}{l}90(57.3) \\
83(39.9)\end{array}$ & 0.001 \\
\hline Grade & $\begin{array}{l}\text { Grade } 11 \\
\text { Grade } 12\end{array}$ & $\begin{array}{l}229(62.7) \\
136(37.3)\end{array}$ & $\begin{array}{l}118(51.5) \\
74(54.4)\end{array}$ & $\begin{array}{l}I I I(48.5) \\
62(45.6)\end{array}$ & 0.594 \\
\hline Having boy/girl friend & $\begin{array}{l}\text { Yes } \\
\text { No }\end{array}$ & $\begin{array}{l}90(24.7) \\
275(75.3)\end{array}$ & $\begin{array}{l}52(57.8) \\
140(50.9)\end{array}$ & $\begin{array}{l}38(42.2) \\
135(49.1)\end{array}$ & 0.257 \\
\hline Perceive at risk of HIV infection & $\begin{array}{l}\text { Yes } \\
\text { No }\end{array}$ & $\begin{array}{l}202(55.3) \\
163(44.7)\end{array}$ & $\begin{array}{l}106(52.5) \\
86(52.8)\end{array}$ & $\begin{array}{l}96(47.5) \\
77(47.2)\end{array}$ & 0.957 \\
\hline Discuss with parents about HIV & $\begin{array}{l}\text { Yes } \\
\text { No }\end{array}$ & $\begin{array}{l}219(60) \\
146(40)\end{array}$ & $\begin{array}{l}120(54.8) \\
72(49.3)\end{array}$ & $\begin{array}{l}99(45.2) \\
74(50.7)\end{array}$ & 0.304 \\
\hline
\end{tabular}

Notes: ${ }^{\mathrm{a} C a t h o l i c, ~ m u s l i m, ~}{ }^{\mathrm{b}}$ Tigre, Gurage, Agaw.

respondents were male and the majority $(86 \%)$ of the participants were Amhara in ethnicity (Table 1).

\section{Knowledge, Attitude and Practice Towards VCT for HIVIAIDS}

From the study participants, the majority (87.4\%) had heard about VCT, 283 (77.5\%) had good knowledge of VCT, $75.5 \%$ had a positive attitude towards VCT and $31.5 \%$ had utilized VCT (Table 2). Three-quarters of the participants $(274 ; 75 \%)$ a had positive attitude towards the VCT service and $77.3 \%$ of them thought that VCT is necessary to prevent HIV transmission (Table 3).

\section{Factors Independently Associated with VCT Utilization}

On bivariate evaluation, 8 variables showed association with the outcome variable, hence were included in the multivariable logistic regression analysis. In this manner four variables were found to be significant. Those variables include; having a boyfriend or girlfriend, discuss with family about HIV, good knowledge and positive attitude towards VCT.

Participants who had a boy/girlfriend were 10.49 times more likely to utilize VCT compared with their counterparts $(\mathrm{AOR}=10.49 ; 95 \%$ CI: 5.48, 20.09). Participants who discuss with their parents were 3.63 times more likely to utilize VCT compared with their counterparts $(\mathrm{AOR}=$ 3.63; 95\% CI: $1.97,6.68)$.

Respondents who had good knowledge utilized VCT services 3.9 times higher than those who had poor knowledge about VCT services (AOR: 3.9; 95\% CI: 1.80, 8.46). Similarly, respondents who had a positive attitude utilized VCT services 3.14 times higher than those who had a negative attitude about VCT services (AOR: 3.14; 95\% CI:1.45,6.82)(Table 4).

\section{Discussion}

This study intended to assess the prevalence and associated factors of VCT utilization and associated factors among Merawi preparatory school students. Voluntary counseling and HIV testing is an important component of 
Table 2 Knowledge Questions About VCT for HIV and Responses Given by the Merawi Preparatory School Students, West Gojjam, Ethiopia, 2019

\begin{tabular}{|c|c|c|c|c|c|}
\hline \multirow[t]{2}{*}{ Variables } & \multirow[t]{2}{*}{ Category } & \multirow[t]{2}{*}{ N (\%) } & \multicolumn{2}{|l|}{ Sex } & \multirow{2}{*}{$\frac{x^{2}}{p \text { value }}$} \\
\hline & & & Male $[\mathbf{N}(\%)]$ & Female $[N(\%)]$ & \\
\hline \multirow[t]{2}{*}{ Have you ever heard about VCT? } & Yes & $319(87.4)$ & $168(52.7)$ & $|5|(47.3)$ & \multirow[t]{2}{*}{0.950} \\
\hline & No & $46(12.6)$ & $24(52.2)$ & $22(47.8)$ & \\
\hline \multirow[t]{2}{*}{ Do you know the place where VCT is provided? } & Yes & $255(69.9)$ & $140(54.9)$ & $115(45.1)$ & \multirow[t]{2}{*}{0.180} \\
\hline & No & $110(30.1)$ & $52(47.3)$ & $58(52.8)$ & \\
\hline \multirow[t]{2}{*}{ Is VCT important for the prevention and control of HIV? } & Yes & $262(71.8)$ & $150(57.3)$ & $112(42.7)$ & \multirow[t]{2}{*}{0.005} \\
\hline & No & $103(28.2)$ & $42(40.8)$ & $61(59.2)$ & \\
\hline \multirow[t]{2}{*}{ Do you know HIV test is conducted voluntarily? } & Yes & $315(86.3)$ & $169(53.7)$ & $146(46.3)$ & \multirow[t]{2}{*}{0.314} \\
\hline & No & $50(13.7)$ & $23(46)$ & $27(54)$ & \\
\hline \multirow[t]{2}{*}{ Do you know HIV testing is given with counseling? } & Yes & $218(59.7)$ & $125(57.3)$ & $93(42.7)$ & \multirow[t]{2}{*}{0.027} \\
\hline & No & $147(40.3)$ & $67(45.6)$ & $80(54.4)$ & \\
\hline \multirow[t]{2}{*}{ Knowledge } & Good & $283(77.5)$ & $153(54.1)$ & $130(45.9)$ & \multirow[t]{2}{*}{0.299} \\
\hline & Poor & $82(22.5)$ & $39(47.6)$ & $43(52.4)$ & \\
\hline
\end{tabular}

intervention for HIV/AIDS prevention and control. The study finding revealed that almost three-quarters (77.5\%) of students had good knowledge about VCT and threequarters of the participants had a positive attitude towards VCT. However, this study revealed that VCT utilization among participants was $31.5 \%$ (95\% CI: 27.1, 37). This result was in line with four prior studies conducted in Ethiopia and with a study done in Malawi which reported prevalence of $31 \%{ }^{18}$ Those Ethiopian studies were Wolkite university students, Mizzen High School Students, Debre Birhan college students and Wachemo University students who reported the proportion of VCT utilization of $29.6 \%, \quad 31.3 \%, \quad 35.2 \%$ and $36.7 \%$ respectively. ${ }^{16,17,19,20}$

On the contrary, the result of this study was lower when compared with a study conducted among Ambo university students (67.2\%), ${ }^{21}$ Ambo secondary school students $(48.36 \%),{ }^{22}$ university students in North West Ethiopia $\left(61.8 \%{ }^{7}\right)$ and secondary school students in Cameroon $(40.5 \%){ }^{23}$ The possible reasons for this discrepancy could be due to variation in the study participant knowledge about VCT, health-seeking behavior, sample size, academic status variation and difference in the sociodemographic characteristics.

On the other hand, our finding was higher than studies conducted in Butajira high school students, Ethiopia $(19 \%),{ }^{24}$ Nigerian youth $(7.1 \%),{ }^{25}$ Addis Ababa high school students $(15.3 \%)^{26}$ and the school youth HIV testing Ethiopian Behavioral Surveillance Survey II report
$(9.3 \%) .{ }^{27}$ The possible explanation for this difference could be due to difference in methods used, sample size, time of the study, perception of confidentiality during the process and school anti AIDS clubs.

By controlling for the effect of other variables through multivariable logistic regression, it was found that students with the following characteristics were more likely to have undergone VCT: having a boyfriend or girlfriend, those who discussed with family about HIV, those who had good knowledge and positive attitude towards VCT.

According to the current study, good knowledge and positive attitude were found to be significantly associated with VCT utilization. This finding was supported by previous studies. ${ }^{7,19,28}$ This could be explained by those who have good knowledge and positive attitude being aware about the prevention methods of the problem, thus working on knowledge and attitude change will facilitate the uptake of the VCT service.

In agreement with other reports, findings of the study further showed that respondents who had a boyfriend or girlfriend were more likely to undertake VCT compared with their counterparts. ${ }^{19,29,30}$ This could be due to the fact that students who enter into relationships have better communication and understand sexual issues. Furthermore, those who had a girlfriend or boyfriend may be more likely to have VCT as a prerequisite to start a sexual relationship and increased their self-efficacy to undertake VCT. 
Table 3 Attitude and Practice of Students Towards VCT Services Among Merawi Preparatory School Students, West Gojjam, Ethiopia, 2019

\begin{tabular}{|c|c|c|c|c|c|}
\hline \multirow[t]{2}{*}{ Variables } & \multirow[t]{2}{*}{ Category } & \multirow{2}{*}{$\begin{array}{l}\text { Number } \\
\text { (\%) }\end{array}$} & \multicolumn{2}{|l|}{ Sex } & \multirow{2}{*}{$\frac{x^{2}}{p \text { value }}$} \\
\hline & & & Male $[\mathbf{N}(\%)]$ & Female $[N(\%)]$ & \\
\hline Do you think VCT is necessary? & $\begin{array}{l}\text { Yes } \\
\text { No }\end{array}$ & $\begin{array}{l}282(77.3) \\
83(22.7)\end{array}$ & $\begin{array}{l}158(56.1) \\
34(40.9)\end{array}$ & $\begin{array}{l}124(43.9) \\
49(59.1)\end{array}$ & 0.016 \\
\hline $\begin{array}{l}\text { Are you interested to take VCT service whether you have it before } \\
\text { or not? }\end{array}$ & $\begin{array}{l}\text { Yes } \\
\text { No }\end{array}$ & $\begin{array}{l}234(64.1) \\
131(35.9)\end{array}$ & $\begin{array}{l}115(49.1) \\
77(58.8)\end{array}$ & $\begin{array}{l}119(50.9) \\
54(41.2)\end{array}$ & 0.077 \\
\hline Do you recommend VCT service for your friends? & $\begin{array}{l}\text { Yes } \\
\text { No }\end{array}$ & $\begin{array}{l}|8|(49.6) \\
\mid 84(50.4)\end{array}$ & $\begin{array}{l}92(50.8) \\
100(54.3)\end{array}$ & $\begin{array}{l}89(49.2) \\
84(45.7)\end{array}$ & 0.501 \\
\hline Do you think VCT is required only for the ill? & $\begin{array}{l}\text { Yes } \\
\text { No }\end{array}$ & $\begin{array}{l}183(50.1) \\
182(49.9)\end{array}$ & $\begin{array}{l}101(55.2) \\
91(50)\end{array}$ & $\begin{array}{l}82(44.8) \\
91(50)\end{array}$ & 0.321 \\
\hline Do you think VCT is only needed for HIV like symptoms? & $\begin{array}{l}\text { Yes } \\
\text { No }\end{array}$ & $\begin{array}{l}137(37.5) \\
228(62.5)\end{array}$ & $\begin{array}{l}75(54.7) \\
117(5 I .3)\end{array}$ & $\begin{array}{l}62(45.3) \\
\mathrm{III}(48.7)\end{array}$ & 0.525 \\
\hline $\begin{array}{l}\text { Do you think couples should undergo VCT for HIV before } \\
\text { marriage? }\end{array}$ & $\begin{array}{l}\text { Yes } \\
\text { No }\end{array}$ & $\begin{array}{l}237(64.9) \\
128(35.1)\end{array}$ & $\begin{array}{l}118(49.8) \\
74(57.8)\end{array}$ & $\begin{array}{l}119(50.2) \\
54(42.2)\end{array}$ & 0.143 \\
\hline Attitude & $\begin{array}{l}\text { Positive } \\
\text { Negative }\end{array}$ & $\begin{array}{l}274(75.1) \\
91(24.9)\end{array}$ & $\begin{array}{l}144(52.6) \\
48(52.7)\end{array}$ & $\begin{array}{l}130(47.4) \\
43(47.3)\end{array}$ & 0.975 \\
\hline Have you ever had VCT service in the past? & $\begin{array}{l}\text { Yes } \\
\text { No }\end{array}$ & $\begin{array}{l}115(31.5) \\
250(68.5)\end{array}$ & $\begin{array}{l}70(60.9) \\
122(48.9)\end{array}$ & $\begin{array}{l}45(39.1) \\
128(51.2)\end{array}$ & 0.032 \\
\hline
\end{tabular}

Table 4 Independent Predictors of VCT Service Utilization Among Merawi Preparatory School Students in West Gojjam, Ethiopia, 2019

\begin{tabular}{|c|c|c|c|c|c|c|c|}
\hline \multirow[t]{2}{*}{ Variables } & \multirow[t]{2}{*}{ Category } & \multicolumn{2}{|c|}{ VCT Practice } & \multicolumn{2}{|c|}{ Bivariable Analysis } & \multicolumn{2}{|c|}{ Multivariable Analysis } \\
\hline & & Yes & No & p-value & COR $(95 \% \mathrm{Cl})$ & P-value & AOR $(95 \% \mathrm{Cl})$ \\
\hline Sex & $\begin{array}{l}\text { Female } \\
\text { Male }\end{array}$ & $\begin{array}{l}45 \\
70\end{array}$ & $\begin{array}{l}128 \\
122\end{array}$ & 0.033 & $\begin{array}{l}\text { I } \\
1.63[1.04,2.55]\end{array}$ & 0.679 & $\begin{array}{l}\mathrm{I} \\
\mathrm{I} .19[0.52,2.7 \mathrm{I}]\end{array}$ \\
\hline Religion & $\begin{array}{l}\text { Orthodox } \\
\text { Protestant } \\
\text { Others }^{\mathrm{a}}\end{array}$ & $\begin{array}{l}71 \\
15 \\
29\end{array}$ & $\begin{array}{l}158 \\
57 \\
35\end{array}$ & $\begin{array}{l}0.098 \\
0.034\end{array}$ & $\begin{array}{l}\text { I } \\
0.58[0.31,1.10] \\
I .84[1.04,3.24]\end{array}$ & $\begin{array}{l}0.330 \\
0.119\end{array}$ & $\begin{array}{l}\mathrm{I} \\
0.66[0.29, \mathrm{I} .5 \mathrm{I}] \\
\mathrm{I} .75[0.86,3.57]\end{array}$ \\
\hline Residence & $\begin{array}{l}\text { Urban } \\
\text { Rural }\end{array}$ & $\begin{array}{l}44 \\
71\end{array}$ & $\begin{array}{l}113 \\
137\end{array}$ & 0.214 & $\begin{array}{l}0.75[0.47, I .18] \\
I\end{array}$ & 0.555 & $\begin{array}{l}0.77[0.34, I .79] \\
\mathrm{I}\end{array}$ \\
\hline Having boy/girl friend & $\begin{array}{l}\text { Yes } \\
\text { No }\end{array}$ & $\begin{array}{l}64 \\
51\end{array}$ & $\begin{array}{l}26 \\
224\end{array}$ & $\leq 0.001$ & $\begin{array}{l}10.8 \mid[6.25, \mid 8.72] \\
\mid\end{array}$ & $<0.001 *$ & $\begin{array}{l}10.49[5.48,20.09] \\
\mathrm{I}\end{array}$ \\
\hline Discuss with parents about HIV & $\begin{array}{l}\text { Yes } \\
\text { No }\end{array}$ & $\begin{array}{l}87 \\
28\end{array}$ & $\begin{array}{l}132 \\
118\end{array}$ & $\leq 0.001$ & $\begin{array}{l}2.77[1.69,4.54] \\
\mathrm{I}\end{array}$ & $\leq 0.00 \mathrm{I}$ & $\begin{array}{l}3.63[1.97,6.68] \\
1\end{array}$ \\
\hline Perceive at risk of HIV infection & $\begin{array}{l}\text { Yes } \\
\text { No }\end{array}$ & $\begin{array}{l}49 \\
66\end{array}$ & $\begin{array}{l}153 \\
97\end{array}$ & 0.001 & $\begin{array}{l}\text { I } \\
2.12[1.35,3.32]\end{array}$ & 0.239 & $\begin{array}{l}\text { I } \\
\text { I.4I }[0.79,2.53]\end{array}$ \\
\hline Knowledge & $\begin{array}{l}\text { Good } \\
\text { Poor }\end{array}$ & $\begin{array}{l}104 \\
11\end{array}$ & $\begin{array}{l}179 \\
71\end{array}$ & $\leq 0.001$ & $\begin{array}{l}3.75[1.90,7.39] \\
\text { I }\end{array}$ & 0.001 & $\begin{array}{l}3.91[1.80,8.46] \\
1\end{array}$ \\
\hline Attitude & $\begin{array}{l}\text { Positive } \\
\text { Negative }\end{array}$ & $\begin{array}{l}104 \\
11\end{array}$ & $\begin{array}{l}170 \\
80\end{array}$ & $\leq 0.001$ & $\begin{array}{l}4.44[2.26,8.74] \\
\text { । }\end{array}$ & 0.004 & $\begin{array}{l}3.14[1.45,6.82] \\
\mathrm{I}\end{array}$ \\
\hline
\end{tabular}

Notes: ${ }^{\text {aC }}$ atholic, muslim; *Value statistically significant; I-reference.

Abbreviations: AOR, adjusted odds ratio; COR, crude odds ratio. 
Finally, in our study finding, we found that discussion about HIV/AIDS within the family was found to be significantly associated with VCT utilization. This result was in line with prior studies. ${ }^{29-31}$ A possible reason for this association could be that open communication in the family might reduce their fear of a positive test result and fear of stigma and discrimination.

\section{Limitation of the Study}

The findings of our study should be interpreted in the context of the limitations encountered. First, the study was conducted on students in one school registered for the academic session at the time of data collection which may not represent other zones in the region as well as in Ethiopia. Second, important variables for sexual behavior, risk perception and knowledge were not assessed, and the cross-sectional nature of the study. Finally, due to the sensitive nature of the topic investigated, there might have been a certain degree of inaccurate responses provided by the participants.

\section{Conclusion}

The study revealed that good knowledge and positive attitude towards VCT services were high. But, utilization of VCT among preparatory school students in the study area was low. There is a need to work on awareness creation to increase the uptake of VCT. The study indicated that having a boyfriend or girlfriend, discussion with parents about HIV, good knowledge and positive attitude towards VCT were significantly associated with VCT utilization.

\section{Abbreviations}

AOR, Adjusted odds ratio; CI, Confidence interval; COR, Crude odds ratio; VCT, Voluntary counseling and testing; KAP, knowledge, attitude and practice.

\section{Ethical Approval and Consent to Participate}

The ethical clearance was obtained from Jimma University institutional review board. Verbal informed consent was approved by the Jimma University Institutional Review Board, and this study was conducted in accordance with the Declaration of Helsinki. Supportive formal letter of permission was obtained from Jimma Institute of Health Ethical review board and given to administrative body of Merawi preparatory school. After this, the objective of the study was described and oral informed consent was obtained from study participants aged $\geq 18$ years and for those $<18$ years old informed consent was taken from the parent (guardian) in accordance with the Declaration of Helsinki. All the communications with study subjects were made with strict privacy and confidentiality and respondents were informed about the procedure, the importance of their participation and the right to withdraw at any time if they wished.

\section{Author Contributions}

All authors made substantial contributions to conception and design, acquisition of data, or analysis and interpretation of data; took part in drafting the article or revising it critically for important intellectual content; agreed to submit to the current journal; gave final approval of the version to be published; and agree to be accountable for all aspects of the work.

\section{Funding}

This research was funded by institute of health sciences, Jimma University.

\section{Disclosure}

The authors declare that they have no conflicts of interest.

\section{References}

1. HIV/AIDS voluntary counselling and testing review_of_policies_programmes_and_guidelines.pdf [Internet]; 2020. Available from: https:// www.who.int/hiv/topics/vct/toolkit/components/policy/review_of_poli cies_programmes_and_guidelines.pdf. Accessed November 24, 2020.

2. Uzochukwu B, Uguru N, Ezeoke U, Onwujekwe O, Sibeudu T. Voluntary counseling and testing (VCT) for HIV/AIDS: a study of the knowledge, awareness and willingness to pay for VCT among students in tertiary institutions in Enugu State Nigeria. Health Policy (New York). 2011;99(3):277-284. doi:10.1016/j.healthpol.2010.11.007

3. Tewabe T, Destaw B, Admassu M, Abera B. Assessment of factors associated with voluntary counseling and testing uptake among students in Bahir Dar University: a case control study. Ethiop J Health Dev. 2012;26(1):16-21.

4. Tsegay G, Edris M, Meseret S. Assessment of voluntary counseling and testing service utilization and associated factors among Debre Markos University Students, North West Ethiopia: a cross-sectional survey in 2011. BMC Public Health. 2013;13(1):243. doi:10.1186/ 1471-2458-13-243

5. Kharsany AB, Karim QA. HIV infection and AIDS in sub-Saharan Africa: current status, challenges and opportunities. Open AIDS J. 2016;10:34. doi:10.2174/1874613601610010034

6. Joint United Nations Programme on HIV/AIDS, United Nations. Global Report: UNAIDS Report on the Global AIDS Epidemic: 2012. Geneva: UNAIDS; 2012.

7. Addis Z, Yalew A, Shiferaw Y, et al. Knowledge, attitude and practice towards voluntary counseling and testing among university students in North West Ethiopia: a cross sectional study. BMC Public Health. 2013;13(1):714.

8. Imanguli N Youth and the global HIV/AIDS pandemic. 2008;30:2009.

9. Ntata PR, Muula AS, Siziya S, Kayambazinthu EE. Gender differences in university students' HIV/AIDS-related knowledge and sexual behaviours in Malawi: a pilot study. SAHARA-J: J SOc Aspects HIV/AIDS. 2008;5 (4):201-205. doi:10.1080/17290376.2008.9724920 
10. Central Statistical Agency. Ethiopia Demographic and Health Survey; 2011. Available from: http://dhsprogram.com/pubs/pdf/FR255/ FR255.pdf. Accessed April 20, 2015.

11. World Health Organization. Service delivery approaches to HIV testing and counseling: a strategic HTC programme framework; 2012. Available from: http://apps.who.int/iris/bitstream/10665/ 75206/1/9789241593877_eng.pdf. Accessed April 20, 2015.

12. World Health Organization/Centers for Disease Control and Prevention. HIV/AIDS progress in 2014: update epidemiology in Ethiopia. Available from: http://www.unaids.org/sites/default/files/ country/documents/ETH_narrative_report_2014.pdf. Accessed April 20, 2015.

13. Charles MP, Kweka EJ, Mahande AM, et al. Evaluation of uptake and attitude to voluntary counseling and testing among health care professional students in Kilimanjaro region, Tanzania. BMC Public Health. 2009;9(1):1-9. doi:10.1186/1471-2458-9-128

14. Yahaya LA, Jimoh AA, Balogun OR. Factors hindering acceptance of HIV/AIDS voluntary counseling and testing (VCT) among youth in Kwara State, Nigeria. Afr J Reprod Health. 2010;14(3):159-164.

15. Federal Ministry of Health, Ethiopia. Guidelines for HIV counseling and testing in Ethiopia; 2007. Federal HIV/AIDS Prevention and Control Office. Available from: https://www.who.int/hiv/topics/vct/ ETH_HCT_guidelinesJune26_clean.pdf. Accessed November 24, 2020 .

16. Ermeko T, Kebede D, Lette A. Knowledge, attitude and practice towards voluntary counseling and testing service among University Students, Southern Ethiopia. Microbiol Res J Int. 2019;1. doi:10.9734/mrji/2019/v28i230126

17. Tesfaye A, Lalisa C, Dejene H, Nigatu D, Tekalign B. Assessment of knowledge, attitude and practice towards voluntary HIV testing and counselling among Mizan High School Students Benchi Maji Zone, Southwest Ethiopia, 2017. Prim Health Care. 2017;7(286):2167.

18. Alister C, Munthali L, Mvula PM, Banda DM. Knowledge, attitudes and practices about HIV testing and counselling among adolescent girls in some selected secondary schools in Malawi. Afr J Reprod Health. 2013;17:60-68.

19. Abdu AO, Teshome G, Melese DM, Girma A, Daniel K, Agizie A. Knowledge, attitude, practice and associated factors of voluntary counseling and testing for HIV/AIDS among Wolkite university students in Ethiopia. J AIDS HIV Res. 2017;9(May):98-105.

20. Gashaw Z. Knowledge, attitude towards practicing of voluntary HIV counselling testing and the determinants of VCT uptake: a case study in Debre Birhan teachers training college. Ethio J Health Dev. 2008;22(3):120-132.
21. Bekele GE, Kensa K, Abebe M. Assessment of knowledge, attitude, practice and determinants of VCT utilization for HIV/AIDS among Ambo University Students, West Shoa Zone, Oromia Region, Ethiopia: cross sectional study. Sci J Public Health. 2015;3(2):259. doi:10.11648/j.sjph.20150302.25

22. Girma T, Tolera D, Melaku F. Factors affecting voluntary counseling and testing VCT among Ambo Secondary School Students, West Shoa, Ethiopia. J AIDS Clin Res. 2016;7(9):2. doi:10.4172/21556113.1000607

23. Nubed CK, Akoachere JF. Knowledge, attitudes and practices regarding HIV/AIDS among senior secondary school students in Fako Division, South West Region, Cameroon. BMC Public Health. 2016;16(1):1. doi:10.1186/s12889-016-3516-9

24. Abebe A, Mitikie G. Perception of high school students towards voluntary HIV counseling and testing, using health belief model in Butajira, SNNPR. Ethiop J Health Dev. 2009;23(2).

25. Oshi SN, Ezugwu FO, Oshi DC, Dimkpa U, Korie FC, Okperi BO. Does self-perception of risk of HIV infection make the youth to reduce risky behaviour and seek voluntary counselling and testing services? A case study of Nigerian youth. J Soc Sci. 2007;14 (2):201-203. doi:10.1080/09718923.2007.11978374

26. Tassew F, Knowledge and attitude towards VCT services; among adolescent high school students in Addis Ababa, Ethiopia. MAY 2005UNAIDS and panos, young men and HIV: culture, poverty and sexual risk, 2001, 13.

27. Mitike G, Mekonnen T, Ayele R, et al. HIV/AIDS Behavioral Surveillance Survey (BSS), Round Two. Ethiopia: Federal Ministry of Health; 2005.

28. Dagne S, Agedew E, Misikir D, Haftu D. Voluntary counseling and testing utilization and associated factors among Arba Minch University Students, South Ethiopia. J AIDS Clin Res. 2017;8 (06):2. doi:10.4172/2155-6113.1000704

29. Fikadie G, Bedimo M, Alamrew Z. Prevalence of voluntary counseling and testing utilization and its associated factors among Bahirdar University students. Adv Prev Med. 2014;2014:1-9. doi:10.1155/ 2014/906107

30. Dirar A, Mengiste B, Kedir H, Godana W. Factors contributing to voluntary counselling and testing uptake among youth in colleges of Harar, Ethiopia. Sci J Public Health. 2013;1(2):91-96. doi:10.11648/ j.sjph.20130102.17

31. Dirar A. Assessment of factors contributing to voluntary counseling and testing uptake among youth in the Colleges of Harar, Ethiopia. Harar Bull Health Sci. 2010;1(1):19-28.

\section{Publish your work in this journal}

HIV/AIDS - Research and Palliative Care is an international, peerreviewed open-access journal focusing on advances in research in HIV, its clinical progression and management options including antiviral treatment, palliative care and public healthcare policies to control viral spread. The manuscript management system is completely online and includes a very quick and fair peer-review system, which is all easy to use. Visit http://www.dovepress.com/testimonials.php to read real quotes from published authors. 